\title{
EUTHANASIA FROM THE PERSPECTIVE OF NORMATIVE LAW AND ITS APPLICATION IN INDONESIA
}

\author{
Agus Hermanto \\ Universitas Islam Negeri (UIN) Raden Intan Lampung \\ Jl. Letnan Kolonel H. Endro Suratmin, Sukarame, Lampung \\ Email: gusher.sulthani@gmail.com
}

\begin{abstract}
There are differences of opinion among scholars regarding the issue of euthanasia. But the element of goodness makes a consideration, that preventing a disease is an obligation that must be done by every individual. While the difference is more depressed on how to apply euthanasia, namely on how to end the suffering of patients. In Islam, scientific and divine healing is known, while in medical science, only rational healing and emergency-based healing are known. In principle, the intentional killing of a sick person precedes fate. God has set the deadline for human life. By speeding up his death, the patient did not benefit from the test given by Allah to him.

Abstrak. Ada pro dan kontra di antara para ilmuwan dalam masalah euthanasia, tapi keduanya sama-sama mengedepankan unsur kemashlahatan, bahwa mencegah suatu penyakit adalah suatu kewajiban yang harus dilakukan oleh setiap individu. Sedangkan sisi perbedaannya lebih tertekan pada cara mengaplikasikan euthanasia tersebut, yakni pada cara mengakhiri penderitaan pasien. Dalam Islam dikenal penyembuhan yang bersifat ilmiah dan ilahiyah, sedangkan dalam Ilmu Kedokteran, hanya penyembuhan yang bersifat 'aqliyah semata dan juga atas dasar unsur darurat. Pada prinsipnya pembunuhan secara sengaja terhadap orang yang sedang sakit berarti mendahului takdir. Allah telah menentukan batas akhir usia manusia. Dengan mempercepat kematiannya, pasien tidak mendapatkan manfaat dari ujian yang diberikan Allah Swt kepadanya, yakni berupa ketawakalan kepada-Nya.
\end{abstract}

Keywords: Euthanasia, Normative Law, Positive Law.

DOI: http://dx.doi.org/10.24239/jsi.v14i2.476.275-300 


\section{Introduction}

Every creature, including humans, experiences a cycle of life that starts from the process of conception, birth, life in the world with its various problems, and ends with its death. From the life cycle process, death is one that still contains a great mystery and science has not managed to uncover it. To be able to determine the death of a person as an individual, the correct diagnostic based on diagnostic concepts that can be scientifically accounted for was carried out. Death as the end of the life sequence is the right of God. No one is entitled to postpone a second, including speeding up the time of death.

Death is generally regarded as something that is very scary, but will be experienced by everyone. Death is a process that can not be delayed, but most people do not want the death to come immediately. Most people hope that death does not come suddenly. People are not only afraid to face death itself, but far more than that, people are horrified to face the circumstances after death occurs.

It is not the same with a person who is desperate to face life because the illness he or she has suffered greatly tormented him. They want immediate death, for which death is not only expected, but also a sought after and desirable thing. Regardless of whether or not they face life after death, they want death soon to arrive. The coveted death of the sufferer, of course, is a normal death in general, far from being painful and horrible. It is this death which in medical terminology is called euthanasia which today is interpreted by the murder of a patient who is hopelessly to be healed.

The progress of science and technology in medical field has made the blurring of line between life and death. Not infrequently someone who has stopped breathing and his heartbeat, thanks to medical interventions such as respirator, can rise again. Sometimes a successful rescue effort is flawless, but sometimes the 
respiratory and heart function returns to normal, without recovering consciousness, which is sometimes permanent. Clinically he is "alive", but socially, he only survives with the help of various medical devices

\section{The Definition of Euthanasia}

Euthanasia is derived from the Greek eumeaning "good", and thanatos, which means "death" which when combined means "good death". ${ }^{1}$ In Arabic, it is called qatlu al-rahmah or taysîr almawt. Muhammad Saltut came up with the term intihar, which means "suicide". Leemen argued that by its very nature it deliberately imposes shortening actions in the lives of others upon the request concerned. ${ }^{2}$ It can also mean a medical action against the severe sufferer (in order to forget all the illness). ${ }^{3}$

According to medical terms, euthanasia means the act to reduce the pain or suffering experienced by someone who will die. It also means accelerating the death of a person who is in great pain and suffering before his death. ${ }^{4}$ According to Yusuf Qardhawi, qatl ar-rahmah is the act of facilitating the death of a person deliberately without sickness, because of compassion, in order to alleviate the suffering of the sick. Thus, euthanasia is often referred to as mercy killing (dead calmly). ${ }^{5}$

From the above definitions, it can be concluded that euthanasia is the effort and assistance made to accelerate the death of a person who is predicted to be near death, in order to relieve or free him from his suffering.

\footnotetext{
1 Setiawan Budi Utomo, Fiqih Aktual Jawaban Tuntas Masalah Kontemporer (Jakarta: Gema Insani Press, 2003), 177.

${ }^{2}$ F. Tengkar, Kematian yang Digandrungi: Euthanasia dan Menentukan Nasib Sendiri (Bandung: Nova, 1991), 29.

${ }^{3}$ Pius A. Partanto, Kamus Ilmiah Populer (Surabaya: Arkola, 1994), 163.

${ }^{4}$ M. Ali Hasan, Masail Fiqhiyah Al-Haditsah: Pada Masalah-Masalah Kontemporer Hukum Islam (Jakarta: Raja Grafindo Persada, 1995), 145.

${ }^{5}$ Yusuf Al-Qardhawi, Fatwa-Fatwa Kontemporer, Vol. 2. (Jakarta: Gema Insani Press, 1995), 749.
} 
Euthanasia is usually done on the grounds that the treatment given to the patient will only prolong his or her suffering. In addition, the treatment itself will not reduce the severe illness he or she has suffered. Or according to medical calculations, the disease is no longer possible to recover or the patient will not last long. Or it could be on the grounds that the patient's family does not have the financial ability to pay for his medication while the treatment continues not to bring positive results.

In the modern world, since the 19th century, euthanasia has sparked debate and movement in North America and in Europe. In 1828 the anti-euthanasia law came into force in the state of New York, which in later years was enacted by several states. After the Civil War, some advocates and doctors supported voluntary euthanasia. Euthanasia supporting groups were originally formed in Britain in 1935 and in America in 1938, which provided support for the aggressive implementation of euthanasia, but the struggle to legalize euthanasia was unsuccessful in America and Britain.

In 1937, euthanasia based on physician advice was legalized in Switzerland as long as the patient did not benefit from it. In the same era, American courts rejected several requests from severely ill patients and some parents with disabled children who applied for euthanasia to the doctor as a form of "merciful murder".

In 1939, German Nazi troops committed a controversial act in a "euthanasia" program for children under the age of 3 who suffer from mental retardation, disability, or other disorders that render their lives useless. This program is known by the name of Action T4 ("Action T4") which later applied also to children over 3 years old and the elderly. After the world witnessed Nazi atrocities in the crimes of euthanasia, in the 1940s and 1950s there was less support for euthanasia and for the unvoluntary euthanasia or euthanasia due to genetic defects. 


\section{The Defition of Death}

Human life is something sacred, therefore human life must be protected and maintained as a privilege given to every human being. Only God can determine when a person is born and when he dies (Q.S. 22: 66; 2: 243). Therefore, suicide is forbidden in Islamic law even though there is no text in the Qur'an or Hadith explicitly forbidding suicide. However, there is a verse that implies that, "And spend in the way of Allah and do not throw [yourselves] with your [own] hands into destruction [by refraining]. And do good; indeed, Allah loves the doers of good." (Q.S. 2: 195), and another verse, "And do not kill yourselves [or one another]." (Q.S. 4: 29), whose immediate meaning is "Let none kill one another." Thus, a Muslim (doctor) who kills another Muslim (patient) is equalized by killing himself.

Euthanasia in the teachings of Islam, called qatlar-rahmahor taisir al-maut, is an act of facilitating the death of a person intentionally without feeling pain, because of affection, in order to alleviate the suffering of the sick, both in positive and negative ways. At the first conference on Islamic medicine in Kuwait in 1981, it was stated that there was no reason to justify euthanasia or mercy killing in any way.

According to dr. Kartono Muhammad, dead is when the brain stem that moves the heart and lungs does not function anymore. According to Peonoh Daly, in relation to death, there are four indication:

1. There is still the motion of breath either little or much motion.

2. There is voice or sound, usually found in the mouth, crying, thirst, and so on.

3. Having the ability to think, especially for adults.

4. Having feelings through the five senses and heart.

Life is real, while death is something secret. A plea for euthanasia on October 22, 2004 has been filed by a husband named Hassan Kusuma since he cannot bear to witness his wife named 
Agian Isna Nauli, 33 years old, lies in coma for two months and in addition to the inability to pay maintenance costs. The application for euthanasia was submitted to the Central Jakarta District Court. This case is one example of euthanasia beyond the wishes of patients. This petition was eventually rejected by the Central Jakarta District Court. After intensive care, the patient's last condition (7 January 2005) had progressed in her health recovery. ${ }^{6}$

\section{Kinds of Euthanasia}

From the view of the condition of patient, euthanasia is categorized into two kinds:

a. Positive or active euthanasia (taisìr al-maut al-fa'āl): an action to speed up the process of death, either by giving injections or removing medical aids, such as releasing acid channels, removing pacemakers and others. For example, there is a malignant cancer patient with tremendous pain until the patient is often unconscious. In this case, the doctor believes the person will die. Then his family suggested that doctors give him a drug with high doses (over dose) at the same time that can eliminate the pain, but stop breathing at once. ${ }^{7}$

b. Negative or passive euthanasia: an act of letting the patient in an unconscious state (comma), because based on experience or medical standard, there is no life expectancy for the patient, perhaps one of the important organs is damaged or weak, such as leaking blood vessels connecting to the brain (stroke) due to high blood pressure, cardiac dysfunction, and so on. This is often called the "intermediate phase", in which the layman calls "between life and death". This negative euthanasia condition for the patient, ie, by discontinuing treatment would most likely

\footnotetext{
${ }^{6} \mathrm{http}: / /$ al-atsariyyah.com/euthanasia-dalam-perspektif-islam.html, (Accessed: 23 October 2015)

${ }^{7}$ Akh. Fauzi Aseri, Euthanasia Suatu Tinjauan Dari Segi Kedokteran, Hukum Pidana Dan Hukum Islam, Dalam Problematika Hukum Kontemporer, ed. Anshary Hafiz and Chuzaimah T. Yanggo (Jakarta: Pustaka Firdaus, 1995), 53.
} 
speed up the death of the patient. This is permissible, possibly due to inadequate funds, or compassion for the patient.

According to the Lisbon Declaration of 1981, euthanasia from the point of humanity is justified and is a right for patients suffering from incurable illness. But in practice, doctors are not easy to carry out euthanasia, because there are two obstacles:

1. The doctor is bound by a medical code of ethics that he is required to help alleviate the suffering of the patient. But on the other hand, if the doctor removes the life of another person, it means he violates the medical code of ethics itself.

2. The act of losing the life of another person is a criminal offense in any country.

Euthanasia is a dilemmatic problem both among doctors, law practitioners, and religious scholars. In Indonesia, this issue has also been discussed, by the Indonesian Doctors Association (IDI) in the seminar in 1985 involving medical experts, legal experts and Islamic jurists, but the result is still no unanimous agreement on the issue. ${ }^{9}$ Likewise, from a religious point of view, some allow the act of euthanasia and some prohibit it, with various arguments or reasons.

\section{Factors Leading to Eutanasia}

There some factors that lead the patient to do euthanasia:

a. Economic factor

One reason for someone to do euthanasia is that the cost required for the treatment is very expensive, so patients are left with a insufficient medical treatment, but the patient requires a optimal treatment to treat the disease. Financial factor is very important in the treatment of patients, especially in this day and

\footnotetext{
${ }^{8}$ Budi Utomo, Fiqih Aktual Jawaban Tuntas Masalah Kontemporer, 178.

${ }^{9}$ Aseri, Euthanasia Suatu Tinjauan Dari Segi Kedokteran, Hukum Pidana Dan Hukum Islam, Dalam Problematika Hukum Kontemporer, 51.
} 
age, all medical equipment are difficult to reach by ordinary people (poor).

b. Medical facilities and staffs

This assumtion is based on the priority of an individual over another individual, on the grounds if there is a young patient who is predicted to be more likely to recover, medical personnel prefer the younger patient. But for a Muslim, this problem is ignored, it is affirmed in the Q.S. Ali Imran: 145:

And it is not [possible] for one to die except by permission of Allah at a decree determined.

Thus, there is no guarantee that patients with mild illness can live longer than patients who are severely ill. Though the death of a person will not happen except by God's will.

\section{c. Decent Death}

This means for dying patients who are given the greatest opportunity to enjoy what they want rather than lying in bed, by giving the drug in lethal doses, so that the patient does not quickly end his life, even though this kind of action is tantamount to suicide and is a major sin in the view of Islam. As narrated by Anas bin Malik that the Prophet said:

No one should wish for deathbecause of a calamity befalling him, but if he has to wish for death he should say: " O Allah ! Keep me alive as long as life is better for me, and let me die if death is better for me"

Therefore, a Muslim must always surrender to Allah and is not allowed to be sorrow during his bad times. Although he must accept the coming of death, one should not lose hope of God's love. ${ }^{10}$

${ }^{10}$ Abdul Fadl Mohsin Ebrahim, Telaah Fiqh Dan Biotika Islam (Jakarta: Serambi Ilmu Semesta, 2001), 154. 


\section{Euthanasia According to Laws in Different Countries}

Euthanasia practices have been reported in various community actions:

a. In India, it has been practiced a habit of throwing old people into the river Ganges.

b. In Sardinia, parents are beaten to death by their eldest son.

c. In Uruguay, freedom of euthanasia practices has been passed in laws since 1933.

d. In some European countries, the practice of euthanasia is no longer a crime except in Norway which treats it as a special crime since 1902 .

e. In the United States, especially in all federal states, euthanasia is categorized as a crime. Suicide or allowing himself to be killed is against the law in the United States.

f. The only country that can take euthanasia action for its members is the Netherlands. The members accepted with certain conditions may request euthanasia on him or her. There are some United States citizens who become its members. In medical practice, there is usually no active euthanasia, but there may be medical practices that can be classified as passive euthanasia.

So far euthanasia is allowed in the following countries:

1. Netherlands. On 10 April 2001, the Netherlands issued laws allowing euthanasia. This law was declared effective on 1 April 2002, which made Holland the first country in the world to legalize euthanasia practices.

2. Australia. The federal state of Northern Territory became the first place in the world with laws allowing euthanasia and assisted suicide, although this reputation does not last long. In 1995, the Northern Territory adopted a law called "Right of the 
terminally ill bill". This new law was implemented several times, but in March 1997, it was abolished by the decision of the Australian Senate.

3. Belgium. The Belgian parliament has legalized euthanasia at the end of September 2002. Euthanasia advocates claim that thousands of euthanasia actions each year have been done since the legalization of euthanasia in this country, but they also criticized the difficulty of this euthanasia procedure so that there is an impression that there is an attempt to create "bureaucratic death". Belgium is now the third country to legalize euthanasia (after the Netherlands and the state of Oregon in America).

In some countries, euthanasia is tolerated. These include among others:

1. In Colombia and Switzerland, lethal Drugs may be given to either Swiss citizens or foreigners if they ask for their own. In general, article 115 of the Swiss Penal Code written in 1937 and used since 1942, which states that "assisting suicide is against the law if its motive is for its own sake." Article 115 is merely an interpretation of a permission to conduct a grouping of drugs that can be used to end a person's life.

2. United Kingdom. On November 5, 2006, Britain's Royal College of Obstetricians and Gynecologists submitted a proposal to the Nuffield Council on Bioethics for consideration of permission to euthanize infants with birth defects (disabled newborns). The proposal is not intended to legalize euthanasia in Britain, but merely to ask for careful consideration of the "possibility of baby's life" as a legitimacy of medical practice. But until now euthanasia is still an unlawful act in the British kingdom as well as in Europe (other than the Netherlands). Similarly, the official policy of the British Medical Association (BMA) expressly opposes euthanasia in any form, and in some countries it is declared a crime. 
3. In the Czech Republic, euthanasia is declared as an act of assassination after the article on euthanasia is excluded from the draft Criminal Code. Earlier in the draft, Prime Minister Jiri Pospísil intends to include euthanasia in the draft Penal Code as a crime with a criminal penalty for 6 years in prison, but the Constitutional Assembly and the country's legal committee recommended that the controversial article be removed from the draft.

\section{Religious Perspective of Euthanasia}

Birth and death are God's prerogative so that no one in this world has the right to extend or shorten its own life. In other words, though a person controls himself, but in fact he is not the full owner of himself. There are certain rules that we must obey and we believe as God's rules. So, even if a person has himself, but still he should not kill himself.

Most of the existing religions do not approve of euthanasia, for several reasons:

1. The doctrine of religion generally states that death is fully God's right, there is no one in this world who has the right to postpone death time, including to speed up the time of death. That people committing euthanasia can be categorized as desperate people, and desperation is not allowed by any religion.

2. All religions have orders and prohibitions in their scriptures, which include among others, the prohibition of killing, be it self or others. If there is command or prohibition, there must be a reward and punishment.

3. Human life is sacred; therefore, human life must be protected and preserved as a privilege given to every human being.

As it is mentioned in other religious teachings:

1. On May 5, 1980, the congregation published the Declaration of euthanasia ("Declaratio de euthanasia") which outlines these 
guidelines further, in particular with the increasing complexity of life support systems and the incessant promotion of euthanasia as a valid means of ending life. Pope John Paul II, concerned about the growing practice of euthanasia, warned us against "the most alarming symptom of the 'culture of death' where increasing numbers of elderly and weak people are considered as an annoying burden." Pope John Paul II also affirmed that euthanasia is a false act of mercy, pseudo compassion: "True compassion encourages to bear the suffering of others, that mercy does not kill people whose suffering we can not bear" (Evangelium Vitae, number 66).

2. Hinduism's view of euthanasia is based on the doctrine of karma, moksa and ahimsa. Karma is a pure consequence of all kinds of intentions of deeds and words, good or bad. As the continuous accumulation, bad karma is a barrier of "moksa" that is a freedom from the cycle of reincarnation which becomes a primary goal of Hindu adherents. Ahimsa is an "anti-violence" principle or abstinence to harm anyone.

3. Buddhism strongly emphasize the meaning of life in which the avoidance to commit the killing of living beings is one of the moral in Buddhist teachings. Based on the above it is clear that euthanasia is something that can not be justified in Buddhism. In addition, Buddhism emphasizes "compassion" ("karuna"). Accelerating the death of an unnatural person is a violation of the main command of Buddhism which can thus become a negative "karma" to anyone involved in decision-making in order to annihilate one's life.

4. The Judaism forbade euthanasia in various forms and categorized it into "murder". The basis of this prohibition can be found in Genesis in the Old Testament Bible Genesis 1: 9 which reads: "But concerning your blood, that is your life, I will exact his vengeance, from every beast I will demand it, and from every man I will claim the soul of fellow human beings". HaKtav 
v'haKaballah explains that this verse is referring to the prohibition of the act of euthanasia.

\section{Normative Law on Euthanasia}

Logically based on the context of the development of science, euthanasia is no problem because it is a consequence of the research and development process. Likewise, in terms of humanity, euthanasia seems to be a commendable act that is to help fellow human beings in ending their misery. But there will be problems when euthanasia is based on other contexts such as law and religion, especially Islam. In the context of law, euthanasia becomes problematic because it relates to the soul or the life of a person, in which by law its existence is highly protected. Whereas in the context of Islamic religion, euthanasia becomes problematic because life and death are derived from His creator.

Expecting death which is manifested through euthanasia is a decision attitude that is hated by God. According to Q.S. Yusuf (12): 87:

“... despair not of relief from Allah . Indeed, no one despairs of relief from Allah except the disbelieving people."

From the above verse it can be understood that desperation is categorized as an attitude of kufr let alone despair leading to death through euthanasia. Even the act of euthanasia in this case leads to a double sin: sin due to the despair of God's grace and the sin of killing oneself directly or indirectly. ${ }^{11}$

Islam recognizes one's right to life and death, but that right is God's gift to man. Only God can determine when a person is born and when he dies, as explained in his word Q.S. al-Hajj: 66:

And He is the one who gave you life; then He causes you to die and then will [again] give you life. Indeed, mankind is ungrateful.

${ }_{11}$ http://keperawatanreligionnabilah.wordpress.com/materi-2/eutha nasia-dalam-pandangan-islam. (accessed: 23 October 2015) 
Therefore, suicide is forbidden in Islamic law even though there is no text in the Quran or Hadith explicitly forbidding suicide. Nevertheless, there is a verse that implies that in Q.S. al-Baqarah (2): 195:

And spend in the way of Allah and do not throw [yourselves] with your [own] hands into destruction [by refraining]. And do good; indeed, Allah loves the doers of good.

Another verse in Q.S. al-Nisa: 9 reads:

And do not kill yourselves [or one another]. Indeed, Allah is to you ever Merciful

The prohibition against killing yourself involves the prohibition of killing others, for killing others means killing oneself, for the people are a unity, whose immediate meaning is "Let not one be killed". Thus, a Muslim (doctor) who kills another Muslim (patient) is equalized by killing himself.

Euthanasia in the teachings of Islam is called qatl ar-rahmah or taisîr al-maut, which is an action to facilitate the death of a person intentionally without feeling pain, because of affection, in order to alleviate the suffering of the sick, both in positive and negative ways. At the first conference on Islamic medicine in Kuwait in 1981, it was stated that there was no reason to justify euthanasia or mercy killing in any way.

In terms of positive or active euthanasia (taisir al-maut alfa'à), it is not allowed by Sharia. For in this act, a physician performs an active action with the intention of killing the sick and accelerating his death through overdose of the drug and this includes the unlawful killing of the law, even including the great sin of destruction. This act is categorized as a murder, ${ }^{12}$ as it is mentioned in the Quran, surah Al-Nisa verse 29. As if it were at the request of the patient, then the patient has endured a very large sin because he has killed himself or had someone else kill him.

\footnotetext{
${ }^{12}$ Al-Qardhawi, Fatwa-Fatwa Kontemporer, 751.
} 
While doctors and family parties who are willing with it all get sins for having a will and even cooperate in the sin.

In general, Islamic teachings are directed to create the benefit of life and human life, so the rules are given in full, both related to civil and criminal matters. In relation to salvation and matters of human life, Islamic criminal law (jinayat) set strict rules, such as the punishment of qisas, hadd, and diyat

Any deeds resulting in the death of another person are included in the category of "criminal action" (jinayat), which gets legal sanction. Thus euthanasia is forbidden by religion and is an act threatened with a criminal penalty. The evidence that states the prohibition against murder includes the Q.S. al-Isra': 33, alNisa': 92, al-An'am: 151. While from the hadith of Prophet SAW, there is a hadith about prohibition killing the infidels who have requested asylum (mu'ahad) (HR.Bukhari).

In principle, the intentional killing of a sick person precedes fate. God has set the deadline for human life. By accelerating his death, the patient did not benefit from the test given by Allah Almighty to him. The Prophet said: "It does not happen to a Muslim man a disaster, either hardship, pain, sadness, distress or disease, even thorns that pierce, unless Allah abolishes his guilt or sin by the calamity that he tried." (HR Bukhari dan Muslim). That is because the right to kill and revive the human is only God and therefore humans in this case have no right or authority to give life and or to turn it off. (QS.Yunus: 56, Al-Mulk: 1-2).

Thus through active euthanasia, it means that man takes the right of Allah, which has become his ordinance. Facilitating the process of death actively as in the first example is not permitted by shari'a. Because that may mean doctors take active action with the aim of killing the sick and accelerating his death through drug delivery in overdose or other means. In this case, the doctor has committed an unlawful assassination, and it is a major sin. 
For man, there is no reason to despair of a disease as long as there is hope, for there is still an obligation to seek. As it is mentioned in the hadith, "no matter how heavy the disease, there is still a cure." (HR Ahmad and Muslim). As for facilitating the process of death by passive euthanasia, it is included in the category of treatment cessation practice. It is based on the doctors' belief that the treatment is useless and does not give hope to the sick, according to the law of cause and effect. This problem is related to the law of doing treatment which is disputed by scholars of islamic law (fiqh) whether it is obligatory or just a sunnah.

According to majority of scholars, to cure or to seek treatment is only recommended (sunnah) and not obligatory (wajib), although a small group of scholars have obliged it, such as the Shafi'iyah and Hanbali scholars as stated by Ibn Taimiyah. The scholars even disagree over which is more important between medication or patience. Among them there is the opinion that patience (not treatment) is more important, based on the hadith Abbas on a woman suffering from epilepsy. The woman asked the Prophet to pray for him, then he replied: "If you will be patient, you will get heaven, and if you will, I will pray to God that He will heal you." The lady replied to be patient and begged the Prophet to pray to Allah so that he does not ask for his illness to be removed, but asked him to pray that her aurat is not exposed when her epilepsy relapses.

In addition, there are many examples from the Companions of the Prophet and their successors who did not seek medical treatment when they were sick. Even among those are who chose illness, such as Ubay bin Ka'ab and Abu Dzar Al-Ghifari. Such attitude is neither reprimanded nor protested by generations of Sahabat and Tabi'in. In this case, the law of treatment or cure of disease is basically mandatory especially if the pain is severe, the medicine is effective, and there is hope to heal in accordance with Allah's orders for treatment. 
Therefore, seeking medical treatment is considered sunnah (recommended) or wajib mandatory if the patient is expected to be healed. Whereas if there is no hope of recovery according to medial consideration, no one says that the treatment is sunnah, let alone mandatory. If the sick person depends on various medications such as injections, infusion artificial respiration, and other modern medical equipment for a long time, but the disease remains unchanged, it is neither compulsory nor recommended, as Yusuf Al-Qardhawi said in his Fatawa Mu'ashirah. Perhaps, it may be even the opposite; no medical treatment is obligatory or sunnah.

Thus facilitating the process of death (taisir al-maut) of this kind in a state of no hope is often termed qatl ar-rahmah (allowing the journey to death of mercy), because in this case, active action from doctors and others is not found. But the doctor or other related person with the patient just leaves something that is not obligatory or recommended. Therefore, he or she cannot be subject to punishment according to shari'ah or positive law. Passive euthanasia action by physicians or doctors in this condition is allowed (jâ'iz) and justified by shariah if the patient's family allow it to ease the suffering and burden of the patients and their families.

This is related to the second example of the former active euthanasia, that is, halting the artificial respiratory device of the patient, which, according to the expert's view, the patient is already "dead" or "categorized as dead" due to brain tissue or neural function are damaged. If the doctor does is just stopping the treatment tool, this is the same as not providing treatment. Thus the problem is the same as other passive euthanasia ways. Therefore, euthanasia for this is not an explicitly active category of euthanasia. Thus, such action is justified by shari'a and is not prohibited, especially if the medical aid equipment is only used by patients for the outward life that appears in breathing and pulse only, but when it is seen medically in terms of activity, the patient is like a dead person, unresponsive, unable to understand 
something and feel nothing, because the brain and nervous tissue as the source of all life's activities have been damaged.

Allowing the sick in such conditions will only cost a lot of energy. It may also prevent the utilization of such equipment by other patients who need it. On the other hand, the patient who cannot feel anything just makes his relatives always in a state of sadness and suffering, which may be up to tens of years.

Among the reasons underlying the permissibility of negative euthanasia is the act of silencing the patients and not treating them. This is one of the opinions among some scholars. That is, the law of healing or treatment of illness is not strictly mandatory. In fact, this opinion is much held by the founders of the schools of law. According to some of them, this law only revolves around mubah. But that does not mean all scholars agree to say that the law treatment is mubah. In this case, some scholars still oblige him to seek treatment. For example, the friends of Shafii, Ahmad bin Hanbal, as Ibn Taimiyah argued, argued that medical treatment and seeking cure is still recommended (mustahab or sunnah).

Ibrahim Hosen states that Islam allows people with AIDS to be deactivated if they meet the following conditions: ${ }^{13}$

1. No medication or vaccine.

2. The health condition is getting worse.

3. Upon his request and his family and with the approval of the doctor.

4. The existence of laws and regulations that permit it

Masjfuk Zuhdi said that even if drugs or vaccines for HIV/AIDS are not found yet and the patient's condition is getting

${ }^{13}$ Masjfuk Zuhdi, "Penderita AIDS Tidak Boleh Dieuthanasia," Mimbar Hukum VII, no. 6 (1996): 28. 
worse, the patient still cannot be euthanized because life and death are in God's hands. ${ }^{14}$ This refers to the Q.S. al-Mulk: 2:

Who has created death and life, that He may test you which of you is best in deed. And He is the All-Mighty, the Oft-Forgiving.

But experience also shows that at times when things that are not explicitly prohibited in the scriptures and declared to be off limits in the view of scholars can change someday. If we pay attention to the practice of passive euthanasia, we can know that in fact the essence of passive euthanasia is the act of stopping the treatment, because it is believed that treatment is not useful and will only add trouble to the patient.

Therefore, this law of passive euthanasia returns to the law of medication itself, whether or not the treatment is compulsory (wajib), recommended (sunnah), or allowed (mubah). If we say the legal treatment is obligatory, then means stopping the treatment (passive euthanasia) the law is forbidden (haram). If we say the treatment is sunnah, then stopping the treatment (passive euthanasia) is makruh. And if we say the treatment is mubah, stopping treatment (passive euthanasia) is mubah. ${ }^{15}$

According to Al-Syafi'I, seeking treatment is sunnah, while Hanafi scholars said that treatment is sunnah muakkadah approaching mandatory (wajib). While Maliki school of law argued that treatment is equivalent between doing or leaving it. Malik said, "It does not matter you go and leave it". Ibn Taimiah said, "Seeking medical treartmentis not obligatory, according to the majority of scholars. Only a small group of Shafi'i and Hanbali scholars who said it is mandatory." 16

\footnotetext{
${ }^{14}$ Ibid., 29

15 http://al-atsariyyah.com/euthanasia-dalam-perspektif-islam.html. (Accessed: 23 October 2015). 2015).

${ }^{16}$ http://al-atsariyyah.com/hukum-berobat.html. (Accessed: 23 October
} 
In short, medical treatment may be sunnah or wajib if the patient can be expected to be healed. If there is no hope of healing, in accordance with medical consideration from doctors, no one says it should be sunnah or wajib. Therefore, facilitating the process of death is not necessarily termed qatl ar-rahmah (euthanasia), because in this case, active action was not found from the doctor.

\section{View of Positive Law on Euthanasia}

Under the law in Indonesia, euthanasia is something against the law. It can be seen in the Criminal Code, Article 344, which states that "Whoever removes the life of another person at the request of the person himself, which he mentions in real and serious manner, is sentenced to 12 years in prison". It is also apparent in the regulation of the Criminal Code, articles 338, 340, 345 , and 359 , which can also be said to satisfy the elements of offense in the act of euthanasia. Thus, formally the law that is applicable in our country does not allow euthanasia.

Farid Anfasal Moeloek, the chairman of the Indonesian Doctors Association (IDI), in a statement published by Tempo magazine on Tuesday, October 5, 2004, said "Euthanasia or "murder without suffering' has so far not been accepted in the values and norms developed in Indonesian society. Euthanasia until now is not in accordance with ethics adopted by the nation."

There are some reasons that prohibit euthanasia:

\section{Legal aspect}

The law contained the Criminal Code only sees doctors as the main perpetrators of euthanasia, particularly active euthanasia and is considered a premeditated murder, or deliberately killing someone's life. Therefore, in the legal aspect, the doctor is always the one who is blamed in the act of euthanasia, regardless of the background of the euthanasia. It does not matter whether the action is at the request of the patient himself or his family, to 
reduce the suffering of the patient in a state of dying or great pain in which the treatment is still unknown. On the other hand, a judge may impose capital punishment on the doctor who do euthanasia toward a person who is still in good condition and still want to live. This is different from the patients wishing for his death like a very distressed patient, without being indicted by the chapter in the law contained in the Criminal Code.

\section{Human righs aspect}

Human rights are always associated with the right to life, peace and so on. It is not clearly stated the right of a person to die. Death seems to be linked to human rights abuses. This is evident from the legal aspects of euthanasia, which tend to blame medical personnel in euthanasia. In fact, with the right to live worthily and so on, it should indirectly arise the right to die, when used to avoid any discomfort or all the great suffering.

3. Scientific aspect

Medical knowledge can predict the likelihood of success of a medical action to achieve healing or reduce patient suffering. If there is almost no possibility of healing or reducing suffering according to medical science, should not a person have a right to renew his or her life? Any effort will be futile, even otherwise, he will be accused of a lie, because in addition to bring no cure to the patients, it will drain a lot of medical cost.

\section{Religious aspect}

Birth and death are the right of God so that no one in this world has the right to extend or shorten his or her own life. This statement, according to religious experts, expressly prohibits the act of euthanasia, whatever the reason. Doctors can be categorized as sinful and resisting the will of God, that is, to shorten life. The one who wants euthanasia because his or her great pain and suffering or even in a state of dying can be categorized as hopeless, and this desperate is not pleasing to God. 
Another aspect of the extention of life when associated with a medical effort in fact can cause other problems. Why people should go to doctors and seek treatment to overcome the illness, if the absolute age at the hand of God. If it is not the time to die, someone will not die. If someone attempts to cure his illness, it can also be interpreted as an effort to prolong life or delay the process of death. Therefore, medical efforts can be disputed as against the will of God. In this case, people often use double standards. If they think something is good, they do not need to look at the existing law, or even find other propositions that can support their opinion. However, when they feel that it is less suitable to their heart, they come up with a variety of arguments to support them.

\section{Medical aspect}

Doctors are not easy to do euthanasia, although from humanitarian point of view, euthanasia is possible and a right for patients who suffer from severe pain that cannot be healed. However, doctors are not justified to immediately make an active effort to meet the wishes of patients or their families. This is due to two things:

a. Due to the problems associated with the medical code of ethics. In one hand, the doctor is required to help alleviate the patient's suffering, but on the other hand, eliminating the life of a person is a violation of the code of ethics itself.

b. The act of depriving the life of another person in the legislation is a criminal offense, which is legally not justified by law in any country.

A doctor must always practice the medical code of ethics as described in KODEKI (Indonesian Medical Code of Ethics). Among general medical obligations of doctors are the following: 
1. Every doctor should uphold and live the doctor's oath (Article 1).

2. A doctor must always do his profession according to the highest measure (Article 2).

3. In performing medical work, a physician shall not be affected by the consideration of personal gain (Article 3).

4. The following acts are deemed contrary to ethics (Article 4)

a. Every act that praises himself

b. By themselves or jointly applying medical knowledge and skills in all forms without professional freedom.

c. Receiving compensation more than appropriate according to his service except with sincerity and the knowledge or the will of the sufferer.

5. Any acts or counseling that may undermine the stamina of human beings both physically and spiritually are reserved for the benefit of the sufferer (Article 5).

6. Every doctor should always be careful in announcing and applying any invention of technique or treatment (Article 6).

7. A doctor only provides information or opinions that can be verified (Article 7)

8. In doing the work, a physician should prioritize the interests of the community and pay attention to all aspects of comprehensive health services (promotive, proventive, quarantative and rehabilitative), and strive to be an educator and serve the actual community (Article 8).

9. Each physician in collaboration with officials in the field of health and other fields must maintain the best mutual understanding (Article 9)

10.Every doctor should always remember the obligation to protect the life of human beings (Article 10). 
11.Every doctor is obliged to be purely sincere and use all his knowledge and skill for the benefit of the patient. In the case of unability to conduct examination or treatment, he must refer the patient to other doctors who have expertise in the disease (Article 11).

12.Every doctor should give the patient the opportunity to stay in touch with his family and counselors in worship and /or in other matters (Article 12)

13.Every doctor must keep everything that is known about a person suffering, even after the patient dies (Article 13).

14.Every doctor is obliged to do emergency treatment as a humanitarian task unless he is sure that someone else is willing and able to give it (Article 14).

15.Every doctor treats his peers as he treats himself (Article 15).

16.Every doctor should not take over the patient from his or her peers without his or her consent (Article 16). ${ }^{17}$

\section{Conclusion}

It is concluded that there are differences of opinion among scholars, but the element of goodness makes a consideration, that preventing a disease is an obligation that must be done by every individual. While the difference is more depressed on how to apply euthanasia, namely on how to end the suffering of patients. In Islam, scientific and divine healing is known, while in medical science, only rational healing and emergency-based healing that are known.

${ }^{17}$ Rekasi New Merah Putih, Undang-Undang Kesehatan dan Praktik Kedokteran, (Yogyakarta: Best Publisher, 2009), 174-177 
In principle, the intentional killing of a sick person precedes fate. God has set the deadline for human life. By speeding up his death, the patient did not benefit from the test given by Allah to him.

\section{References}

Aseri, Akh. Fauzi. Euthanasia Suatu Tinjauan Dari Segi Kedokteran, Hukum Pidana Dan Hukum Islam, Dalam Problematika Hukum Kontemporer. Edited by Anshary Hafiz and Chuzaimah T. Yanggo. Jakarta: Pustaka Firdaus, 1995.

Budi Utomo, Setiawan. Fiqih Aktual Jawaban Tuntas Masalah Kontemporer. Jakarta: Gema Insani Press, 2003.

Ebrahim, Abdul Fadl Mohsin. Telaah Fiqh Dan Biotika Islam. Jakarta: Serambi Ilmu Semesta, 2001.

Hasan, M. Ali. Masail Fiqhiyah Al-Haditsah: Pada Masalah-Masalah Kontemporer Hukum Islam. Jakarta: Raja Grafindo Persada, 1995.

Partanto, Pius A. Kamus Ilmiah Populer. Surabaya: Arkola, 1994.

Qardhawi al-, Yusuf. Fatwa-Fatwa Kontemporer. Vol. 2. Jakarta: Gema Insani Press, 1995.

Tengkar, F. Kematian Yang Digandrungi: Euthanasia Dan Menentukan Nasib Sendiri. Bandung: Nova, 1991.

Zuhdi, Masjfuk. "Penderita AIDS Tidak Boleh Dieuthanasia." Mimbar Hukum VII, no. 6 (1996).

http://keperawatanreligionnabilah.wordpress.com/materi2/euthanasia-dalam-pandangan-islam. (accessed 23 October 2015)

http://al-atsariyyah.com/euthanasia-dalam-perspektifislam.html, Download: 23 October 20 (accessed 23 October 2015) 15 
Vol. 14, Number 2, December 2017: 275-300

http://al-atsariyyah.com/hukum-berobat.html, (accessed 23 October 2015) 